Portland State University

PDXScholar

5-24-2019

\title{
The Life, Composing and Impact of Kenny Wheeler
}

Quinn Walker

Portland State University

Follow this and additional works at: https://pdxscholar.library.pdx.edu/honorstheses Let us know how access to this document benefits you.

Recommended Citation

Walker, Quinn, "The Life, Composing and Impact of Kenny Wheeler" (2019). University Honors Theses. Paper 676.

https://doi.org/10.15760/honors.690

This Thesis is brought to you for free and open access. It has been accepted for inclusion in University Honors Theses by an authorized administrator of PDXScholar. Please contact us if we can make this document more accessible: pdxscholar@pdx.edu. 
The Life, Composing and Impact of Kenny Wheeler

by

Quinn Walker

An undergraduate honors thesis submitted in partial fulfillment of the requirements for the degree of

Bachelor of Music

In

University Honors

And

Jazz Studies, Emphasis in Trumpet Performance

Thesis Advisor

George Colligan

Portland State University

2019 


\section{ABSTRACT}

Since its birth in the beginning of the twentieth century, jazz music has had an immense impact on the world. As jazz began to grow, many sub-genres developed within jazz, incorporating elements of blues, funk, rock, free music, and complex harmony. As a jazz musician myself, something always fascinates me is the diversity within the genre. With the development of steaming platforms such as Spotify, it has never been easier to discover the immense amount of jazz that musicians have gifted to this world. The popularity of jazz music has been in steady decline since the 1960s. This has resulted in many of the lesser-known jazz musicians to go unrecognized by the public as a "jazz greats," unlike names everyone knows, such as Miles Davis, Duke Ellington, and John Coltrane.

The Canadian born trumpet and flugelhorn player Kenny Wheeler has always stood out to me as an incredibly versatile and original composer, who has stretched the boundaries of jazz music. Wheeler has had an enormous impact on my musical studies-pushing me to compose more than I have ever before, and making me question the limits of jazz composition, like he did in his career. Studying Wheeler's life and composing is a vehicle for me to work on my own composing and musicianship. Thorough analysis of Wheeler's music has led me to many ideas that I transfer into my own music, and has given me context into what Wheeler was possibly thinking when he sat down to write his inventive music.

As the last portion of this project, I have prepared a performance of five original Kenny Wheeler songs for jazz ensembles of varying size, from trio to septet. I personally transcribed and arranged all of the music for the concert and presentation on Kenny Wheeler. Doing this allowed me to get inside the mind of the great composer, and get a deeper look at the possible inspiration for his writing style. For one of my arrangements, I decided to broaden my own 
arranging skills by creating a sound that was unlike what Wheeler composed, while still using his melodic and harmonic ideas as scaffolding. This was no simple task, because Wheeler's music is already so individual to him and him only; it is a great challenge to arrange his music to sound different than the iconic recordings he released decades ago. 


\section{WHEELER'S EARLY LIFE: INTROVERTED EXCELLENCE}

Kenneth "Kenny" Vincent John Wheeler was born January 14, 1930, in Toronto, Ontario

to a lower-middle class family. Wheeler's family in Canada was not immune to the Great

Depression that famously hit the United States in the 30s; the turbulence of the Depression

forced Wheeler's family to move around Canada in his early years, until they settled first in St.

Catharines and then later in Windsor. (Vogel, 2016) Wheeler's father was a semi-professional

musician, and was the one who introduced his son to music. In an interview with Mark Miller in

1980, Wheeler talked about when his father brought him home his first trumpet:

"[My father] didn't teach me, he just brought it home one day. I didn't take much interest in it for a few months, and then I started fooling around with it. I played in a military band in Windsor, a sea cadet band. I remember we all wore a navy type of uniform and went along once or twice a week to play in this band. The bandmaster, I think his name was Wood or Woods, Petty Officer Woods, taught me a bit. When I went to high school in Windsor, we had a small jazz band; it wasn't really a school band, just a few fellows who got together. I was maybe 14 by then. I had been interested in jazz already for a couple of years. My father being a semi-professional musician, and my brother playing a little, meant there was always music in the house. In listening to the dance band kind of music, I began to hear the other kind of players as well. The first was Buck Clayton. At that time he was on quite a lot of records-Billie Holiday records, Kansas City things.”(Miller, 1980)

While researching Wheeler's musical upbringing, I was surprised to hear that he went through a very traditional jazz route for musicians of that time. He went on to have one of the most unconventional jazz careers in the history of the music, so I expecting — probably hopingthat his first musical experiences were unique; however, they were not. He got his start, just like so many other jazz musicians did — by playing military band music and jazz dance band music. Perhaps I was hoping that his earliest musical influences would be unconventional twentiethcentury classical music like Ravel or Schönberg; my prediction proved incorrect, as Wheeler's 
introduction to music ended up being the jazz dance bands of the 20s. In an interview with Roger

Cottrelle in 1979, Wheeler talks about his first musical influences and his early life:

"The town I grew up in, St. Catharines was fairly small. It has tripled in population now, but it was about 50,000 population at that time. My father was a professional musician in the twenties and then he became a semi-pro. Although he liked jazz, his interest was more in the dance band thing-Tommy Dorsey, Glenn Miller. But at least there was always music around the house. I guess there was some sort of line of progression. First of all, I was interested more in the Chicago people and Wilbur de Paris, Wingy Manone, "Wild" Bill Davidson. Then I heard Buck Clayton, Roy Eldridge-people like that. I got on to jazz that way. I don't say you progress up to Buck Clayton, Roy Eldridge and so on. It wasn't like that... I think a lot of people think jazz is a question of learning that bit, then you go on to somewhere else and forget the earlier stuff. But it's not like that; it's the whole thing.'(Cottrelle, 1979)

Upon further exploration into jazz as a young man, Wheeler began developing his

musical tastes that would lead to him to his unmistakable sound that he developed later in life.

His unique blend of traditional jazz elements with a modern twist came from a direct lineage of players, who influenced his soul when he was young. Wheeler's tastes differed from that of the typical budding jazz musician of the late 40s. While many musicians that came up in that period cited two jazz trail blazers as their main influences during the period, Dizzy Gillespie and Charlie Parker, Wheeler was attracted to the softer and more subtle side of jazz at the time. He favored artist like Miles Davis and Coleman Hawkins, and developed a love of sad melodies, as exemplified in the quote below:

"I have always loved beautiful melodies. I must be a little twisted because beautiful sad melodies make me feel very happy-because they communicate to me. I think one of the first records which really affected me was the Coleman Hawkins recording of "Body and Soul." I was fifteen at the time, and the first time I heard it, I immediately burst into tears, not so much with sadness - it just communicated to me." (Strum, 1997)

From an early age, Wheeler began developing and broadening his musical tastes. Of course, Wheeler was also a fan of bebop, saying that his initial reaction to the new, fast music was that he did not like it; but over time, Wheeler grew to love bebop music with the help of his 
musical acquaintances of the time. Nonetheless, Wheeler's love of beautiful melodies stuck with him for his entire composing career. (Cottrelle, 1979)

In 1952, Wheeler was itching to broaden his musical horizons, and move away from the small Canadian cities he had spent his whole life in. Unlike many jazz musicians of the time, Wheeler was not interested in moving to one of the great American jazz cities like New York or Chicago. With the Korean War at its peak, Wheeler naturally did not want to get enlisted; but his desire to move on from Canada was too strong.

"I just wanted to go anywhere, but you know, I didn't have the nerve to go to Cuba or South America, which I would have liked to have done. In England they spoke the same language, and I knew that if I came into any kind of trouble I could always just run into the nearest Canadian embassy and cry out Help! While in South America I'd probably have been kicked in jail or something, wouldn't I? (Lees, 1995)

With the encouragement of friend Gene Lees, Wheeler decided to move to London, England at the age of twenty-two, and start a new musical journey that would lead to his prolific career. Although the original plan was to move with Lees, he never arrived, and so Wheeler moved to London on his own. Upon his arrival to London, Wheeler was not revered as the trumpet giant he is today. On the contrary, he felt like no one really liked his playing, and selfdoubt seemed to consume him. This self-doubt was something that plagued Wheeler throughout his entire career. While self-doubt may be considered a negative aspect for musicians in almost all aspects, it let Wheeler develop himself as a musician before releasing any of his own music; he did not release his first album as a leader until 18 years after his arrival in London. In an interview with Roger Cotterell, Wheeler explains how he felt as a musician moving to England:

When I got to London, the first few nights I found some jazz clubs. I found out where people like (alto saxophonist) Joe Harriott and (trumpeter) Tony Cromble were playing. Some of the best players around. I asked to sit in. I thought I was pretty good, but from them I got no reaction whatsoever. You know, I thought hey would at least say that was terrible or that was good or something. They let me play but they acted as though I wasn't 
there. It sort of shook me and I went into my shell for a few months and got a day job in a post office. (Cotterell, 1979)

Wheeler spent most of the fifties performing in a plethora of different English jazz dance bands, with band leaders Roy Fox, Ronnie Rand, Derek New, Tommy Whittle, Buddy Featherstonhaugh, and Woody Herman. (Vogel, 2016) Wheeler continued to play in dance bands throughout the sixties, but was becoming increasingly frustrated with the role he was playing in jazz music. This frustration led him to seek out new musical experiences, which led him to find a group of Europeans that would greatly influence him in the future.

I always tried to play bebop, but I never could play it, I don't think I could play it till this day. As much as I love it and it's my roots, but... I never could play five or six choruses of "I Got Rhythm" in the idiom, you know. I'd get a bit nervous and go out, do something else, so I wasn't really accepted in England by the bebop crowd actually. But I was dying to play- I didn't know what I wanted to play, and knew I couldn't really play bebop... Then I found out about this little theatre [The Little Theatre Club] where John Stevens was playing, they had sessions playing free jazz once a week, I guess that was sort of the start of the free jazz movement in England more or less... It must have been 1966 the first time I came in there. I went up there one night to listen, and I hated it, what they were playing. But I stayed on, and then I came back another night and they said - why don't you come and sit in? So I sat in, and I just went completely berserk on the trumpet, let out a lot of frustrations, cause I'd been dying to play a lot. As I said, I didn't feel I was accepted by the "in" players because I couldn't really play a "straight" chorus in their language, so I just kept on playing with these guys. (Husby, 1981)

It was during this time period that Wheeler was actively developing into the type of player and composer that he would be for the rest of his career, especially as a leader. Wheeler was living a double life in the jazz community, trying to fit in with the "straight ahead" jazz crowd and the "free" jazz crowd simultaneously. This blend of modernism and respect for jazz tradition allowed Wheeler to carve out his unique path in jazz history. During this transformative time, Wheeler prioritized listening to music that seemed to align with that same mix of modernism and jazz tradition. One musician that stood out to Wheeler was trumpet player Booker Little. Little's music “opened up" Wheeler's understanding of what it meant to play with 
the limits of respecting the tradition of jazz while still playing in a more unique fashion. Wheeler said on the subject:

"So I thought, 'Oh, you can do things differently and still be in the tradition.' That gave me the courage to have faith in my own thing and not feel guilty because I couldn't play strict bebop. And I have found that one helped the other. If I got a normal sort of jazz gig with tunes, I felt the free jazz helped. And, in turn, the straighter playing helped my free playing. Free jazz helped loosen me up on changes, and the traditional gigs brought my free playing in a bit. (Lees, 1995)

In 1975, after obtaining more than twenty years of experience in the industry, Wheeler finally released his debut small-group jazz album entitled Gnu High - an album that some jazz musicians today herald as the "Kind of Blue of the 70s"(Tressler, 2014). This sort of reputation was a huge honor in the jazz community, as it compared Gnu High to the best selling jazz record of all time. Naturally, Gnu High ended up setting the stage for the rest of Wheeler's career. Not only did that album display Wheeler's completely unique approach to playing and composing, but the sidemen on the album—Dave Holland, Jack DeJohnette, and Keith Jarrett-—all went on to become some of the most influential musicians of all time on their respective instruments. From there, Wheeler's career exploded, and he went on to release twenty-eight albums of his own, and to take part in countless recordings, until his death in 2014.

As a leader and as a sideman, Wheeler went on to work with many of the jazz world's most important figures, including Keith Jarrett, Jan Garbarek, Clark Terry, Michael Brecker, Dave Holland, Chris Potter, Jack DeJohnette, Bob Brookmeyer, Charlie Haden, Paul Motian, Anthony Braxton, Woody Herman, Philly Joe Jones, Johnny Dankworth, Evan Parker, John Stevens, Mike Westbrook, John Taylor, Norma Winstone, Globe Unity Orchestra, Lee Konitz, John Abercrombie, Paul Gonsalves, Stan Sulzmann, John Parricelli, Chris Laurence, Martin France, and many more. 
Walker 8 


\section{WHEELER'S COMPOSING STYLE: A MIX OF JAZZ TRADITION AND MODERNISM}

From the moment when I was first introduced to Kenny Wheeler's music, I was hooked. I remember the moment when I was playing in a local Portland jazz combo, and the leader put the sheet music for Wheelers “Three for D'reen.". When I glanced at the music, I can recall that my initial thoughts 1 were something along the lines of, "That looks really hard, and those chord changes make no sense." After playing through the chart, I instantly realized that there was a lot more to this music than just the mere complexity of Wheeler's writing style. I have always found that Wheeler's music makes much more sense to the ears than it does to the eyes. While Wheeler used complex chord changes and oddly placed melodies, all of his music is rooted in jazz tradition and functional harmony. He incorporated a clever mix of modern composition techniques and traditional jazz form and harmony to create his original sound.

For my purposes, I closely analyzed three of Wheeler's compositions that I will also be playing for the performance portion of my project. The three compositions that I analyzed are "Everybody’s Song but My Own", "Nicolette" and "Heyoke". In each analysis, I focus on a different aspects of Wheeler's writing, including form, harmony, melody, and root movement.

In the 1988 album Flutter By, Butterfly, Wheeler released a song entitled "Everybody's Song but My Own." One of the only Wheeler songs to be considered somewhat of a jazz standard, this song is played even today in jazz venues frequently across the world. A major reason why this song is still popular is because of its relation to jazz tradition. The song was written in the most standard song form in all of jazz: AABA form. Utilizing smooth root movement, odd but logical melody construction, and the aforementioned standard jazz form Wheeler achieved a song that sounds like it comes from jazz tradition, but clearly was uniquely fresh and unconventional. 

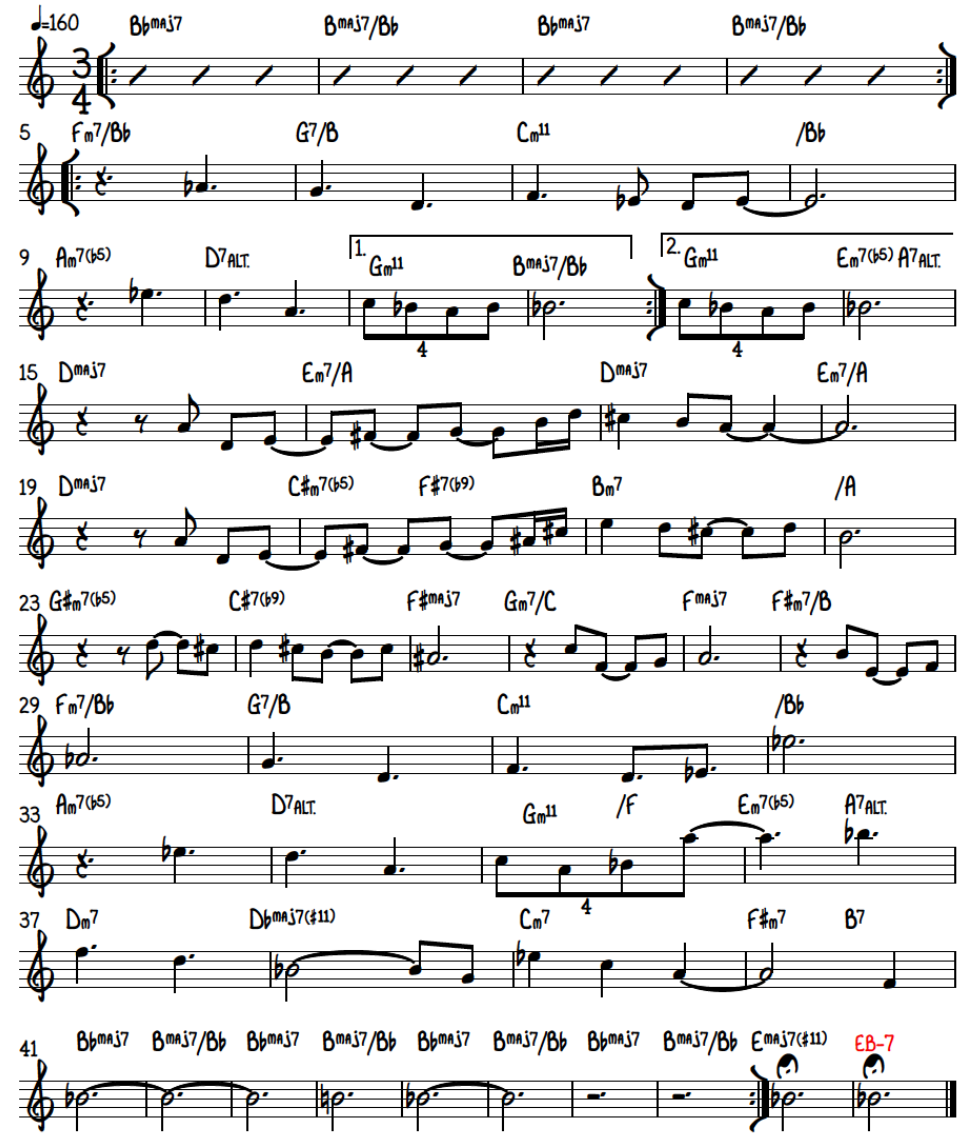

Figure 1: Lead Sheet for Kenny Wheelers "Everybody's Song But my Own”

As seen in figure 1, the melody of "Everybody's Song but My Own” does not start on beat one, like so many jazz standard melodies do. In every phrase of the melody until the final A section, the melody starts on the "and" of 2 . This approach to writing melody leaves the listener with tension every time a new phrase is introduced, because beat 1 is the "ultimate resolution beat" for a melody; when it starts on a different beat, naturally, the listener will be waiting for the melody to resolve (Galper, 2003). When in the final A section, Wheeler writes the melody to start on beat 1 , resolving the tension that he has created throughout the tune. Not only does the displacement of melody in the first three sections of the song (AAB) create a tension that needs 
to be resolved, when it is finally resolved in the last A, the result is a natural peak of energy. The delay of the peak of the song makes it tell a great story with a beginning (A1.A2), a middle (B), and a strong ending (A3).

The root movement of "Everybody's Song but My Own” is also notable. For the large majority of this song, the root of every chord rarely moves more than either a half step or a whole step. This is a theme that is prevalent in many of Wheeler's compositions. Close-knit root movement is a technique that allows Wheeler to use many different tonalities in his compositions, while still staying somewhat functional harmonically. When moving roots in very small intervals (half and whole steps), they will often seem to make sense aurally. When not using close root movement, Wheeler utilizes the most used functional chord movement in jazz: the ii-V-I chord progression. This tune is the perfect example of Wheeler employing composing methods that respects jazz tradition, while still illuminating his own compisitional sensibilities.

To illustrate how closely related "Everybody's Song but My Own" is to many charts in the American Songbook, I took the liberty of changing a few of its aspects; my goal was to make it reminiscent of songs written by Tin Pan Alley composers. Below is my adapted version of "Everybody's Song but My Own" that will be played during the performance portion of my project; I will be playing it directly after the original version of the song. The changes that I made to the song are small, which demonstrates that I did not have to do much to it. I changed the meter of the song from the original 3/4 to the more standard 4/4 time, and utilized a medium swing feel. The one other facet I changed was some of the chords to better match up with music that someone like Cole Porter might have written. Many of original chords I have left the same, because many of them were already in the vein of composers like Porter. Finally, in an attempt to stay true to Wheeler, I left the melody as is. 


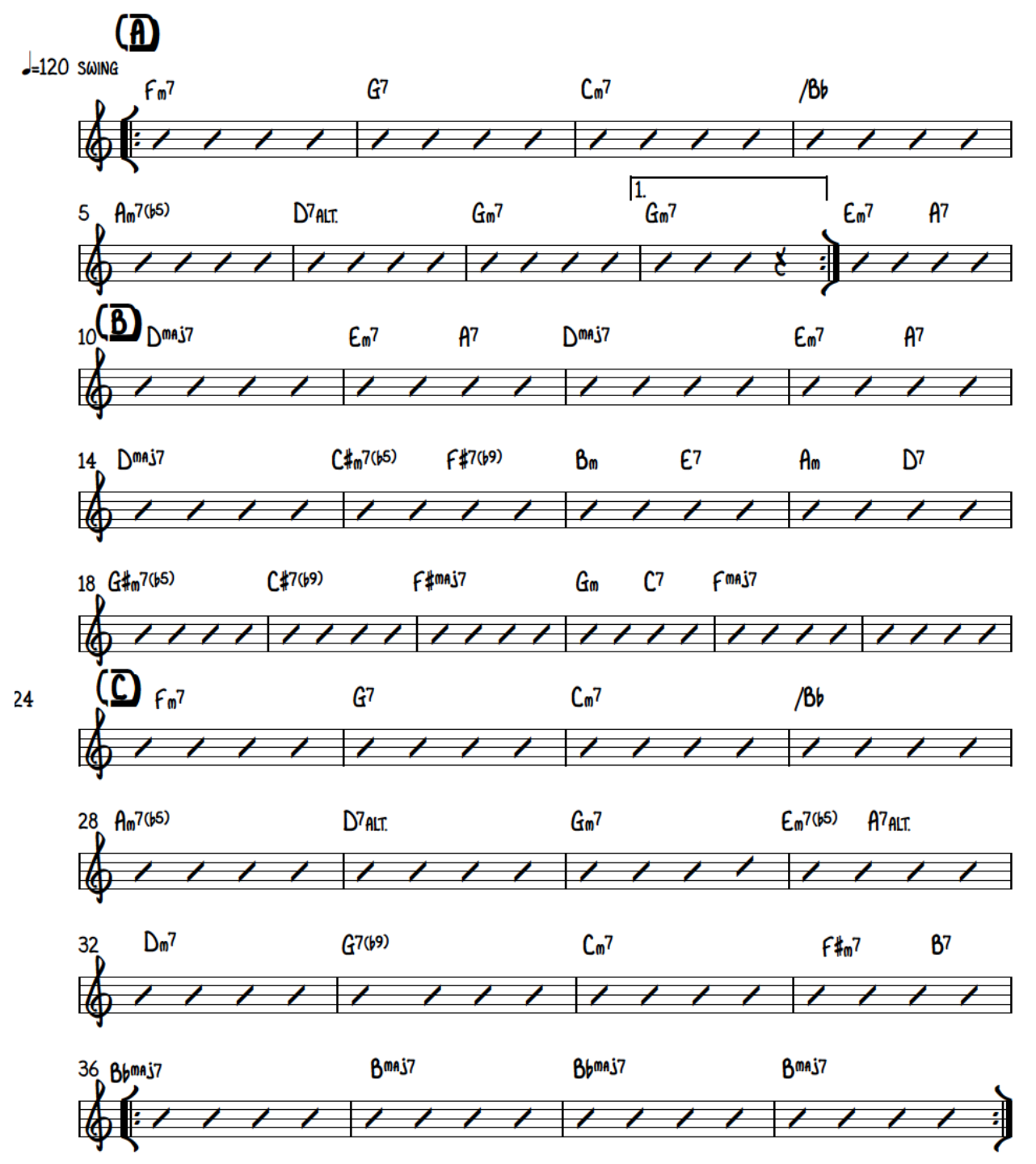

Figure 2: Adapted version of "Everybody's Song but My Own"

Throughout Gnu High, Wheeler applies modern composing techniques that connect directly with the jazz lineage. In the song "Heyoke," Wheeler used a composing technique developed by great saxophonist John Coltrane. This technique, aptly named "Coltrane changes," is achieved by a song by writing in tonalities that split an octave into equal parts.

In Coltrane's famous jazz standard "Giant Steps," he split the octave into three major thirds, that together created an augmented triad. Those three notes became the tonalities for the 
song (B major, G major, and Eb major). Coltrane employed dominant chords between the three tonalites $(\mathrm{B}, \mathrm{G}$ and $\mathrm{Eb})$ of the song to modulate cleanly between the chords. Seen in the figure 3 below, during the first ending of "Heyoke," Wheeler uses this same approach. However, unlike Coltrane, Wheeler does not use dominant chords to modulate and instead uses chordal planning between the three chords creating an augmented triad (F major, A major, and Db major).

Wheeler's approach has more of a modern feel to it than Coltrane's does, because of the lack of the dominant chord creating a resolution when the new tonal centers are presented. Wheeler also uses major7\#11 chords instead of just major chords, a chord that just sounds a lot more "modern" than the regular major chord.

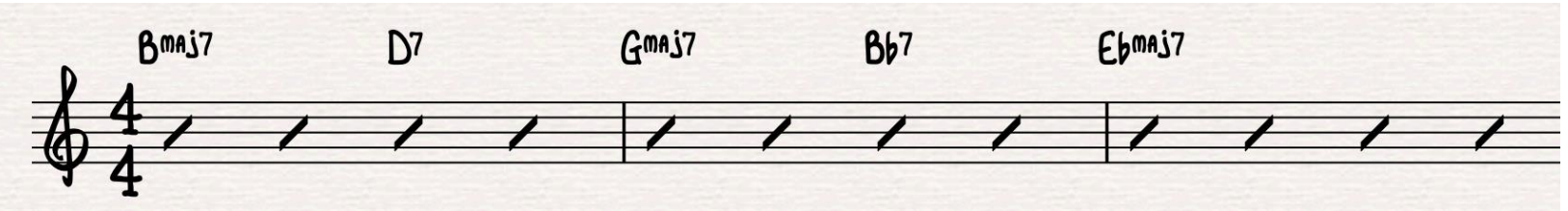

Figure 3: Chord Changes to John Coltrane's “Giant Steps

9

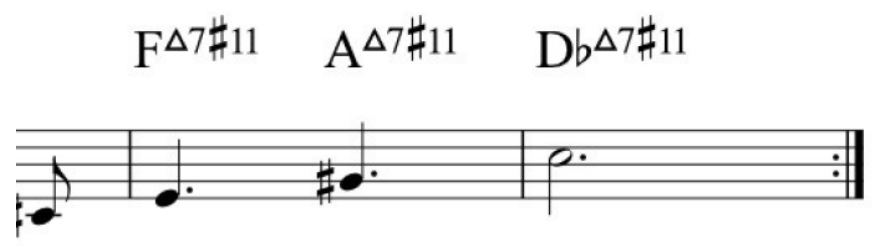

Figure 4: Chord changes to bar 11 and 12 of Wheelers "Heyoke"

Wheeler's song "Nicolette" is a great example of his gift of writing odd but beautiful melody. In "Nicolette," the melody incorporates large intervallic leaps that are very unusual for normal jazz composition. The melody of the song uses the major 7th interval most, appearing twelve times in the melody of the song(Humphries, 20019). (Exemplified in figure 5 below, I 
have circled all of the instances where the major 7th interval is used.) Use of large intervallic leaps in the melody added to "open" quality of Wheeler's music, and became a defining factor for his compositions. He also applied a similar technique in "Heyoke," wherein the two first melodic phrases start with three perfect fourths (Figure 6)

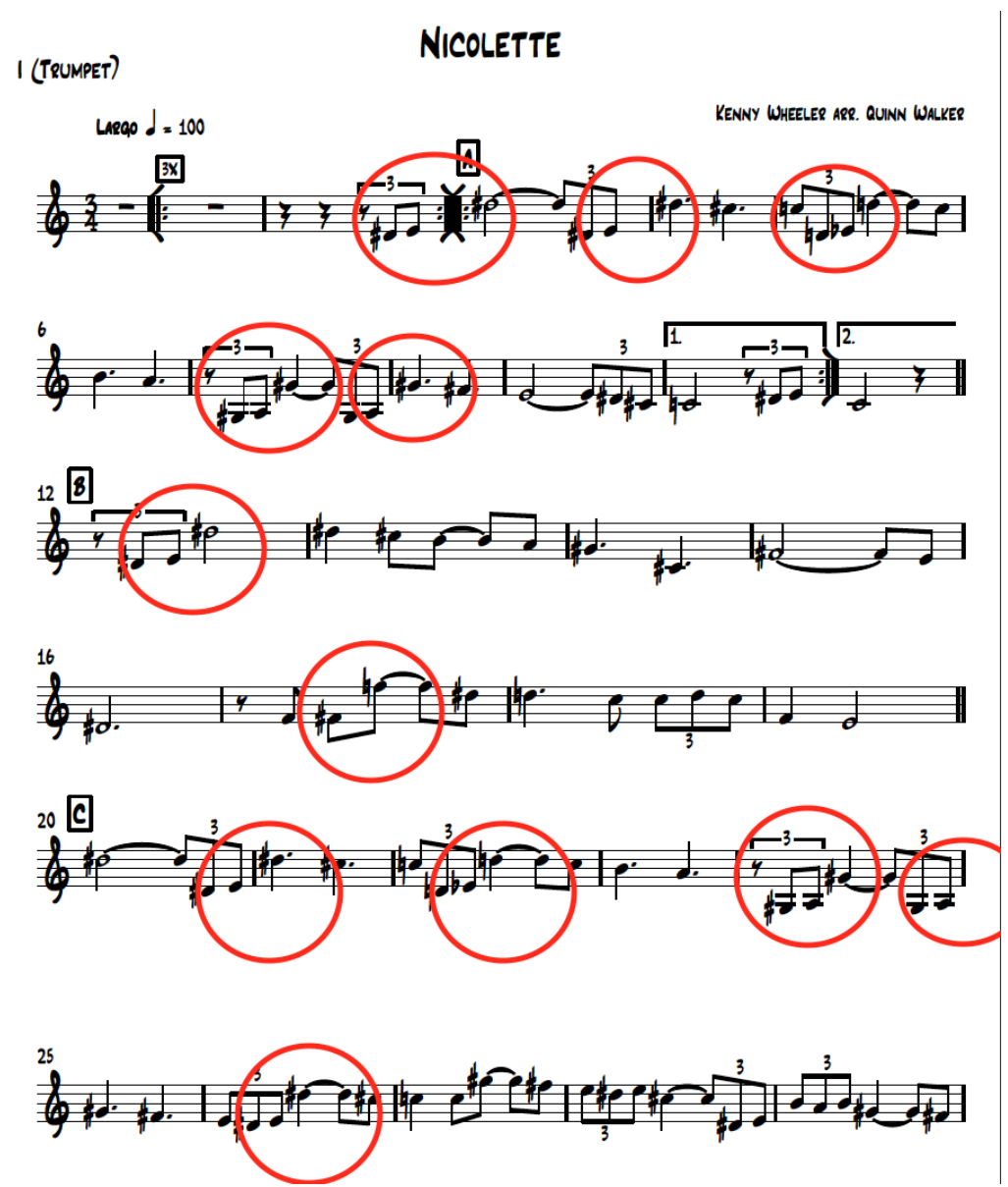

Figure 5: Wheelers "Nicolette" with major 7th intervals circled in red. 

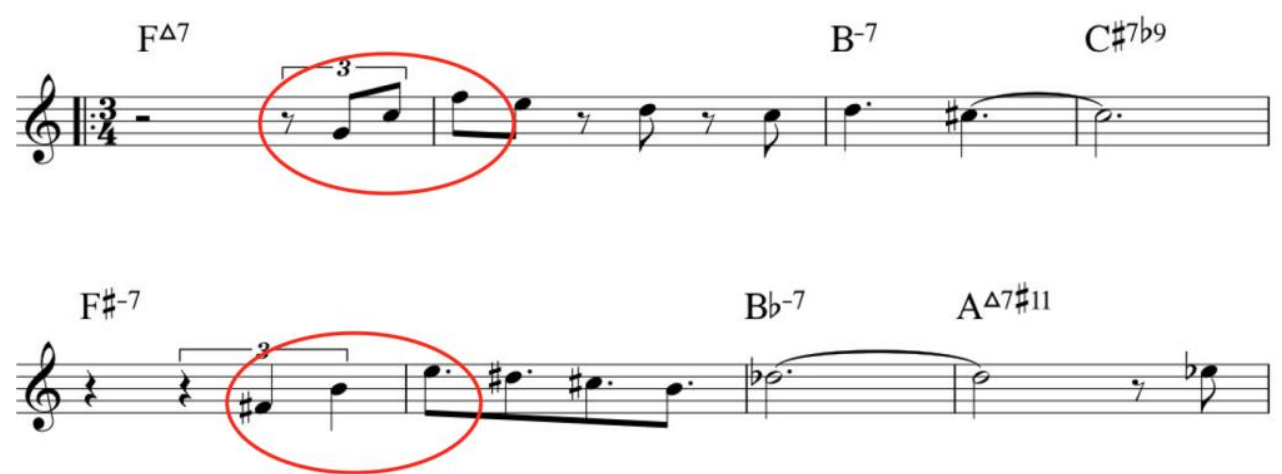

Figure 6: Wheelers use of stacking 4ths in the melody of "Heyoke". 


\section{ARRANGING, PERFORMING, AND PRESENTING ON WHEELER'S MUSIC}

My arranging professor, Ezra Weiss, told me that when deciding a song to arrange, to avoid choosing music that already has a definitive sound. Giving examples of musicians like Charles Mingus, Wayne Shorter, and Maria Shnieder, Weiss explained the simple fact: you're not going to make this music better than it already is. A big reason why I latched on to Wheelers playing and composing is because how definitively individual he is as a musician. Wheeler created a sound world that is not easily copied, and is not easily arranged to sound like anything other than a Wheeler transcription. For this reason, I decided to only arrange one of the 6 songs I played to try to put my own 'mark' on the music. The song I chose was "Heyoke" from debut ECM album Wheelers Album Gnu High.

"Heyoke" seemed to have to most room to work with compared to the other songs in my set. The original recording of the song has no intro, and Wheeler was the only horn player. This gave me a lot of room to take liberties, compared to songs like "Foxy Trot" and "Nicolette" that are heavily dependent on the counter melody line Wheeler wrote for the melody to work.

The three main aspects of the song that I changed were group size, feel changes, and form. After deciding that I was going to use a jazz septet with four horns (trumpet, alto sax, tenor sax, baritone sax), the first thing that I decided to change was the feel. I felt like changing the 'swing in three' feel to a $12 / 8$ elvin jones style afro cuban beat would make the song feel very different. For this arrangement this was essentially an exercise in making "Heyoke" sound new. Next, I decided that a bassline would serve as a good intro and accompiant to the drum groove. For the remainder of the song the feel switches back and forth between the new afro cuban groove and the original swing feel. 
The next aspect of the chart I changed was the form. I felt like the last four bars could be repurposed as a longer vamp style section. I did this by repeating the last four bars, and then transposing those same four bars up a minor third and repeating the transposed section twice. At the end of the building 16 bar vamp section I added a short break section that leads into the solos; using the horns to make a cascade of minor seventh chords moving down in minor thirds.

The extra horns really provided me a great opportunity to add my own mark to Wheelers existing composition. For the "A" section of the song I completely harmonized the melody using all of the horns. In the "B" section of the melody I wrote countermelody lines and hits using the horns as well. I also wrote backgrounds for the solos and tried to make them guide the soloist to a shape that I had envisioned for the solos. Below is the basic lead sheet for "Heyoke", the score can be found in the appendix. 

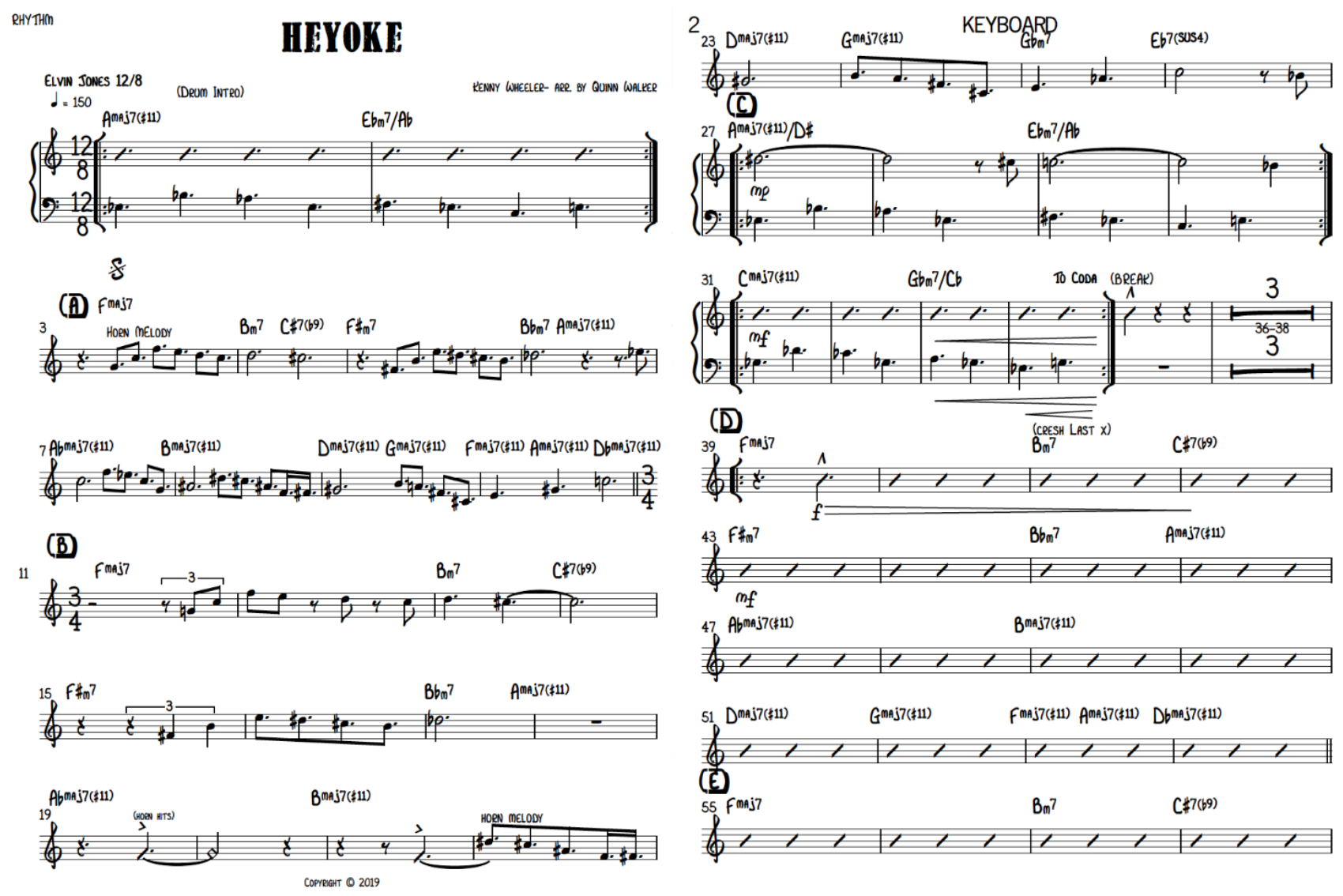

Figure 7: "Heyoke" lead sheet arranged by Quinn Walker

For the rest of the songs I played at the concert I stuck to my original transcriptions of Wheelers music, with the exception of "Nicolette" and the second swing feel version of "Everybody's Song but My Own”. In between the songs I gave short lectures based on the topics of discussion found in this paper: Wheelers life, influences, composing devices, and what I have taken away from this study of Wheeler. The full scores of all the music I played for the performance portion of my project can be seen in the appendix. 


\section{CONCLUSIONS}

After researching Wheeler thoroughly, I feel like a big gap in my knowledge about the history of jazz has been filled. I remember not too long ago still feeling like I had for years, asking myself: How on earth did Kenny Wheeler develop such a distinctive voice in the lineage of jazz? I have discovered the answer to be his incredibly unique life and set of circumstances that set him on his path to become one of jazz's greatest composers. Wheeler continued to develop as a musician while living the dual life of a lover of the tradition of jazz and the new sounds of avant guard and free jazz simultaneously. This led him to sop up all of the music that was around him in the 40s, 50s and 60s and develop himself as an incredibly skilled composer and trumpet player before he released any of his own albums.

This project has also been incredibly helpful to me as a musician. It has helped me work on and display my arranging skills in a performance setting. It has provided me historical, and compisitional context that is extremely valuable to as a striving jazz performer, composer, and arranger. The project has especially helped me refine my own composing skills, because now I have that many more concepts to work with when I go to write a song myself.

Kenny Wheeler should be remembered as one of the quiet pioneers of jazz. When everyone was starting to reject jazz in favor of other kinds of popular music, Wheeler was still able to acknowledge the great history of jazz while carving an entirely new path of his own. Wheeler has taught me what it means to be an innovator in the jazz world: find a way to put your mark on the things you love about jazz music. 


\title{
REFERENCES:
}

\section{Texts}

Galper, H. Forward Motion. Pub. O'Reilly Media Inc. 2003.

Gene Lees,“An Absolute Original: A Profile on Kenny Wheeler,1995

Humphries, A. "Kenny Wheeler: Melody, harmony and structure”. 2009.

Mark Miller,“Kenny Wheeler’s Many Vehicles,” Down Beat, April 1980

Per Husby. "Kenny Wheeler: Interview," Cadence, May 1981

Roger Cotterell, “Kenny Wheeler: Speaking Softly But Carrying a Big Horn,”Jazz Forum, 1979.

Steve Tressler, Jazz Night In America: Tribute to Kenny Wheeler, PBS, 2014

Sturm, Fred. Kenny Wheeler: Collected Works on ECM. Vienna: Universal Edition, 1997.

Vogel, A. Angel Song: The Suite Life and Music of Kenny Wheeler, May 2016

\author{
Albums \\ Wheeler, Kenny. Gnu High. ECM.(1976) \\ Wheeler, Kenny. Deer Wan. ECM (1978) \\ Wheeler, Kenny. Around 6. ECM. (1980) \\ Wheeler, Kenny. Double Double You. ECM. (1984) \\ Wheeler, Kenny. Music for Large and Small Ensemble. ECM. (1990) \\ Wheeler, Kenny. Angel Song. ECM. (1997) \\ Wheeler, Kenny. What Now? CAM jazz. (2004) \\ APPENDIX \\ Scores of Arrangements of Kenny Wheeler Music for Performance
}


"Everybody's Song but My Own"

\section{EVERYBODYS SONG BUT MY OWN}

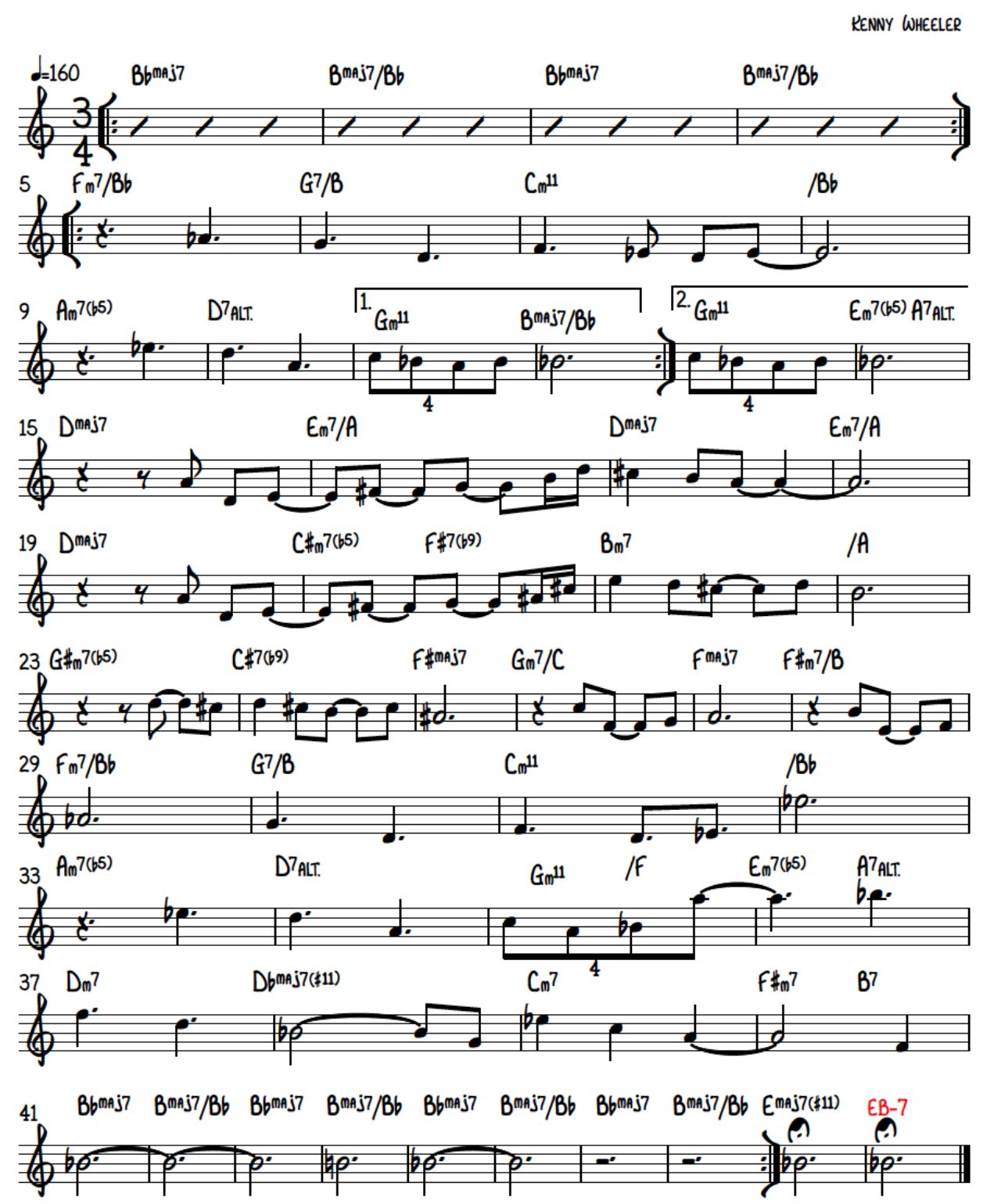

“Everybody's Song but My Own” - Swing Version arranged by Quinn Walker 
Walker 22

EVERYBODY SWING BUT MY OWN: SWING VAR.

K. WHEELER, ARR $Q$ WALLER

(A)

$d=120$ SWING
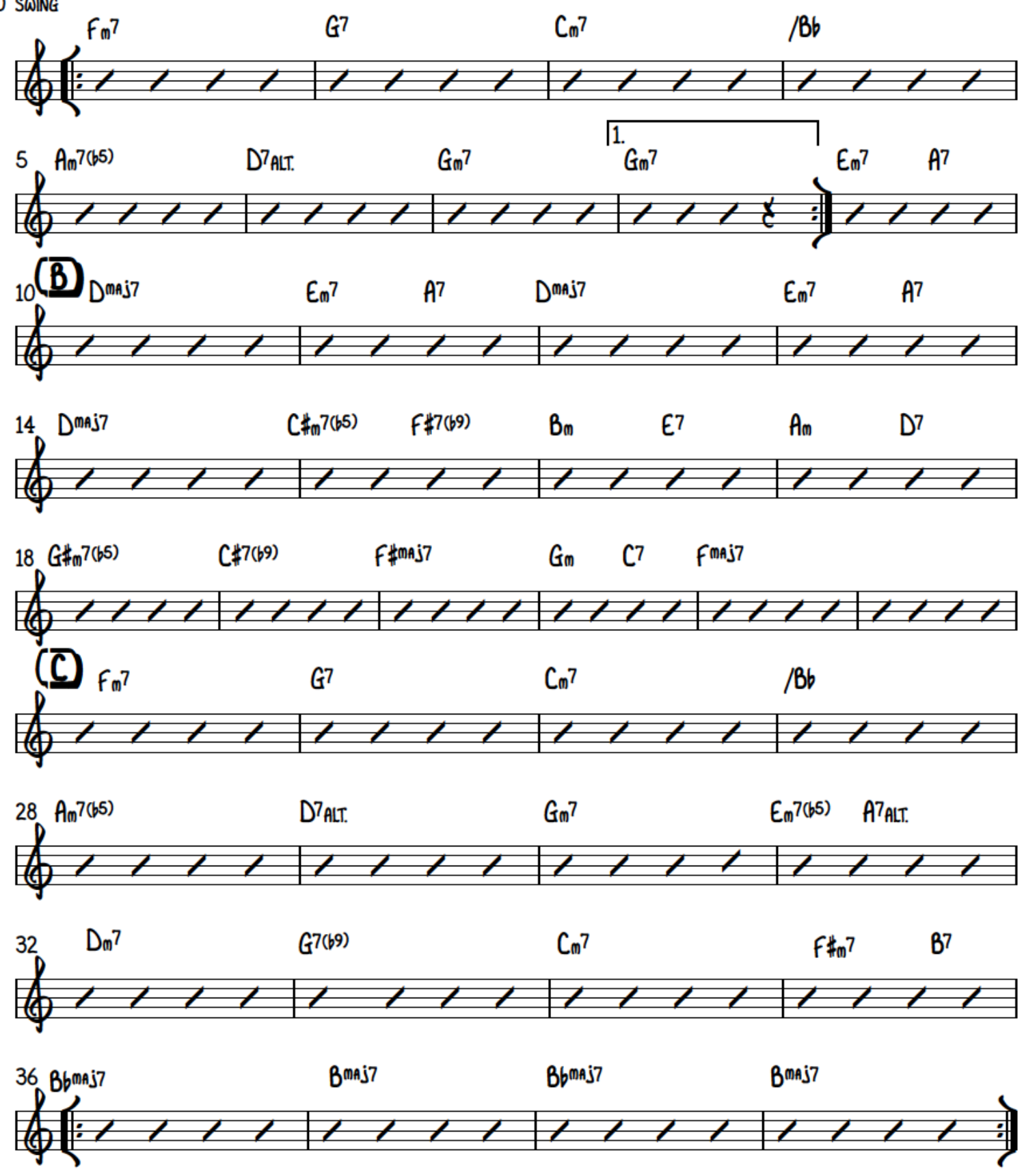
Walker 23

"Foxy Trot"

CONCERT

FOXY TROT

d=160 STRAIGHT 8TH ECM RUBATO PNO INTRO OVER MAIN MELODY, TIME BEGINS AT D

KENNY WHEELER
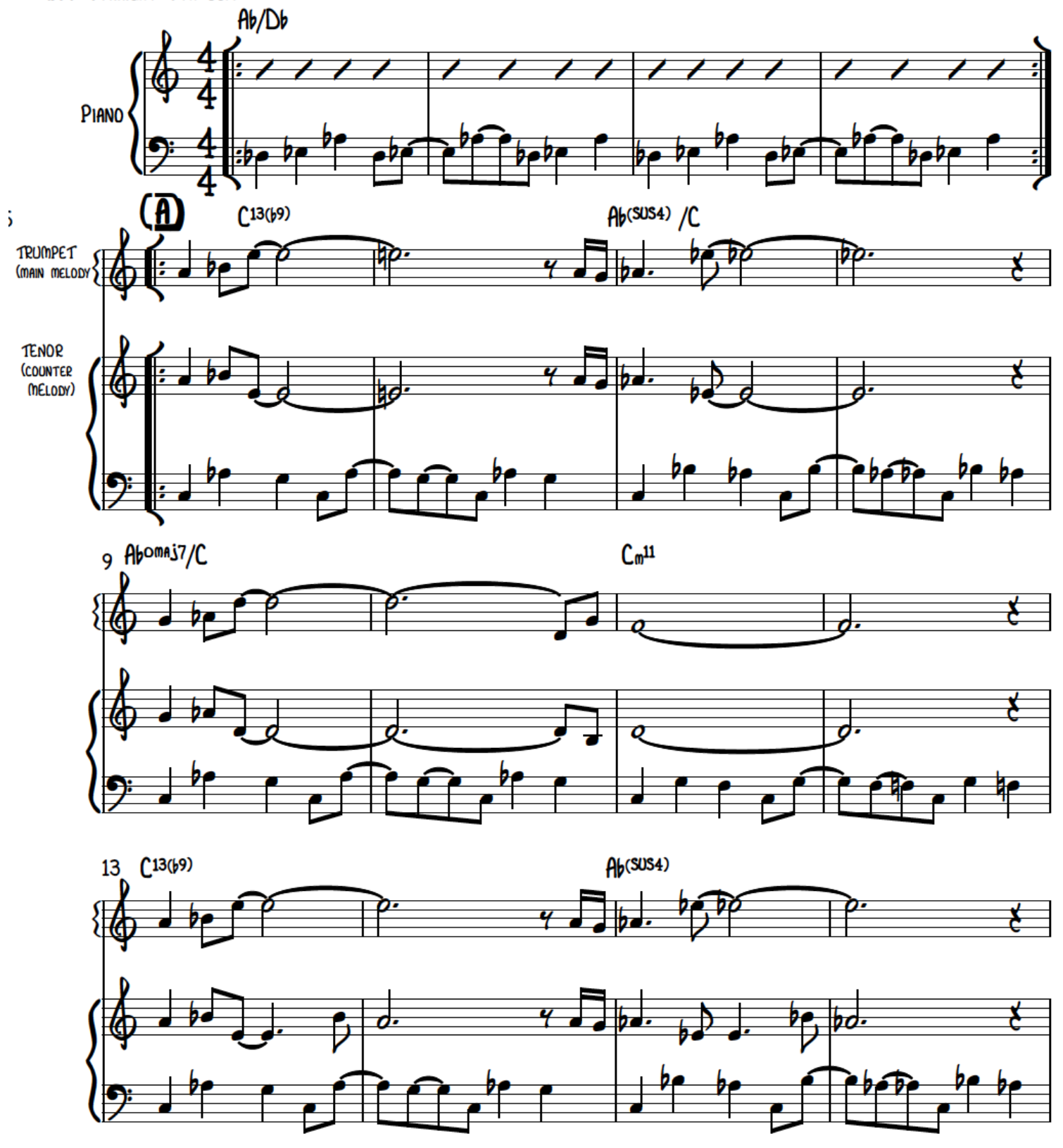
Walker 24

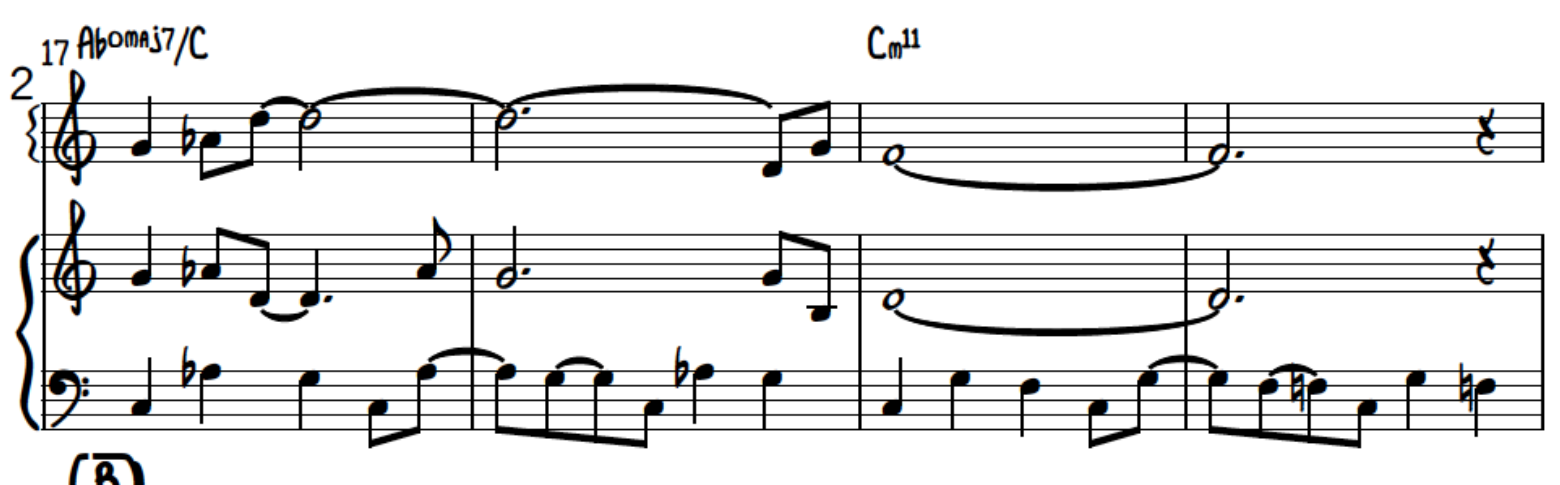

(B)
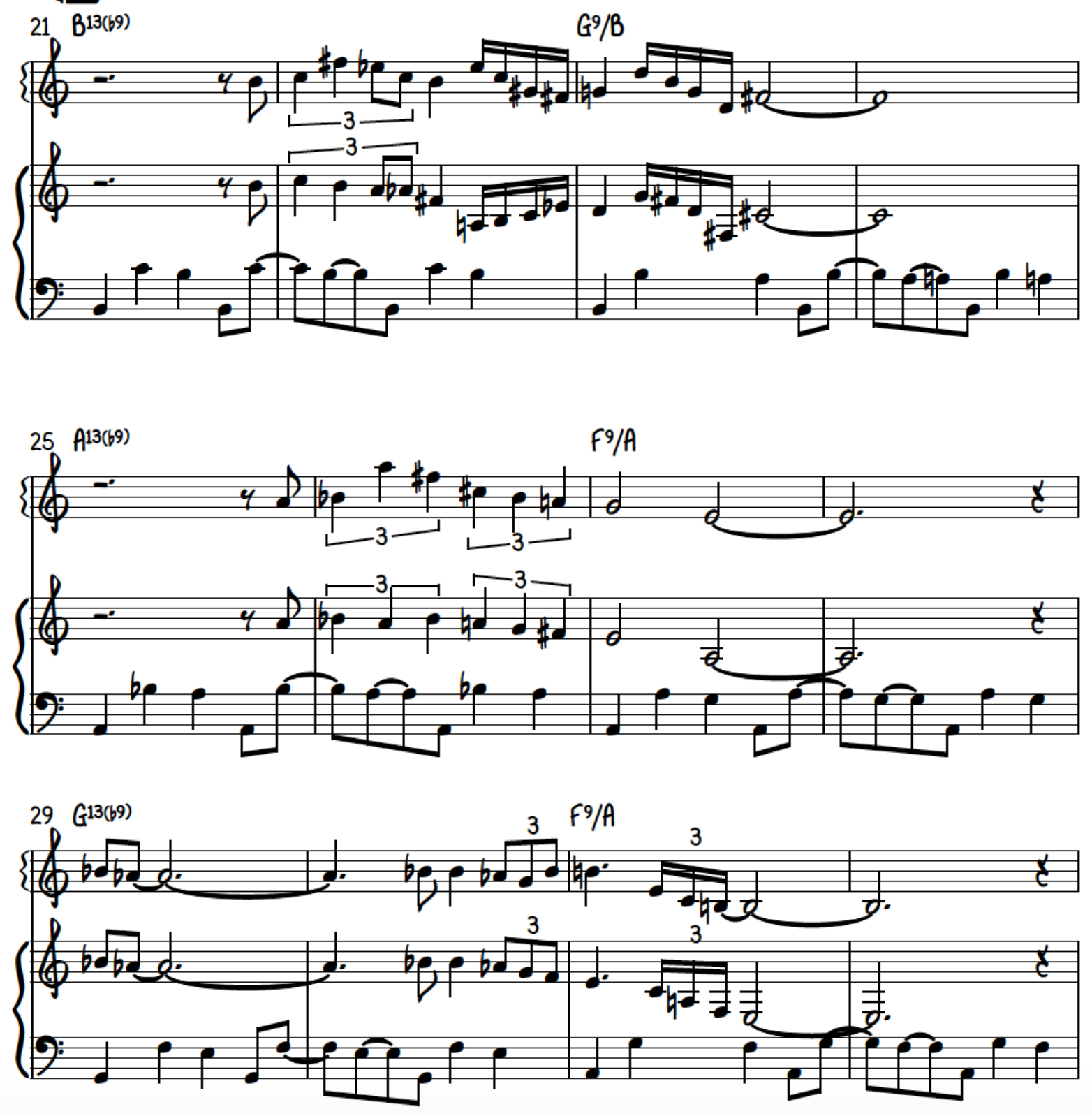
Walker 25
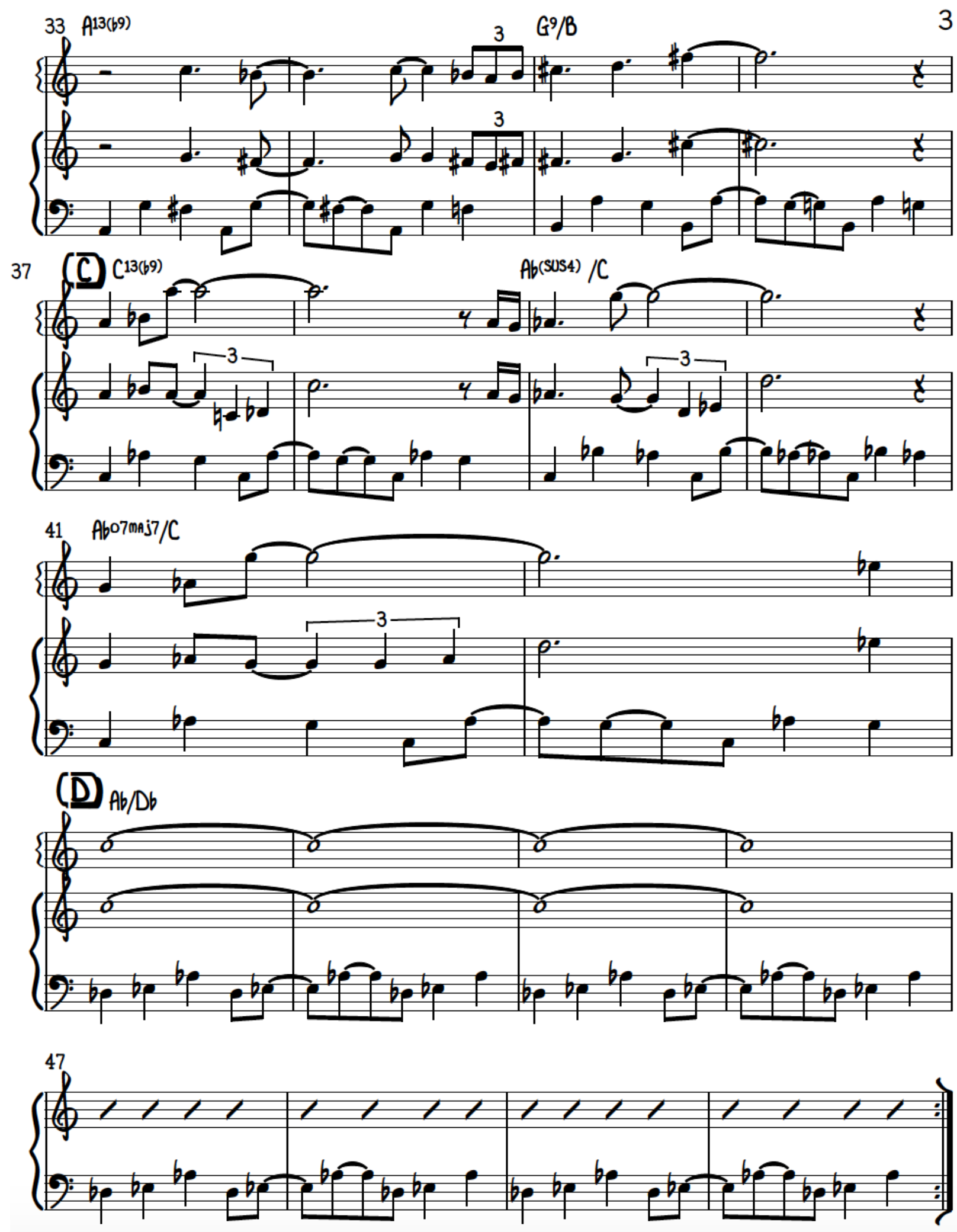
Walker 26

"Heyoke" arranged for jazz septet by Quinn Walker

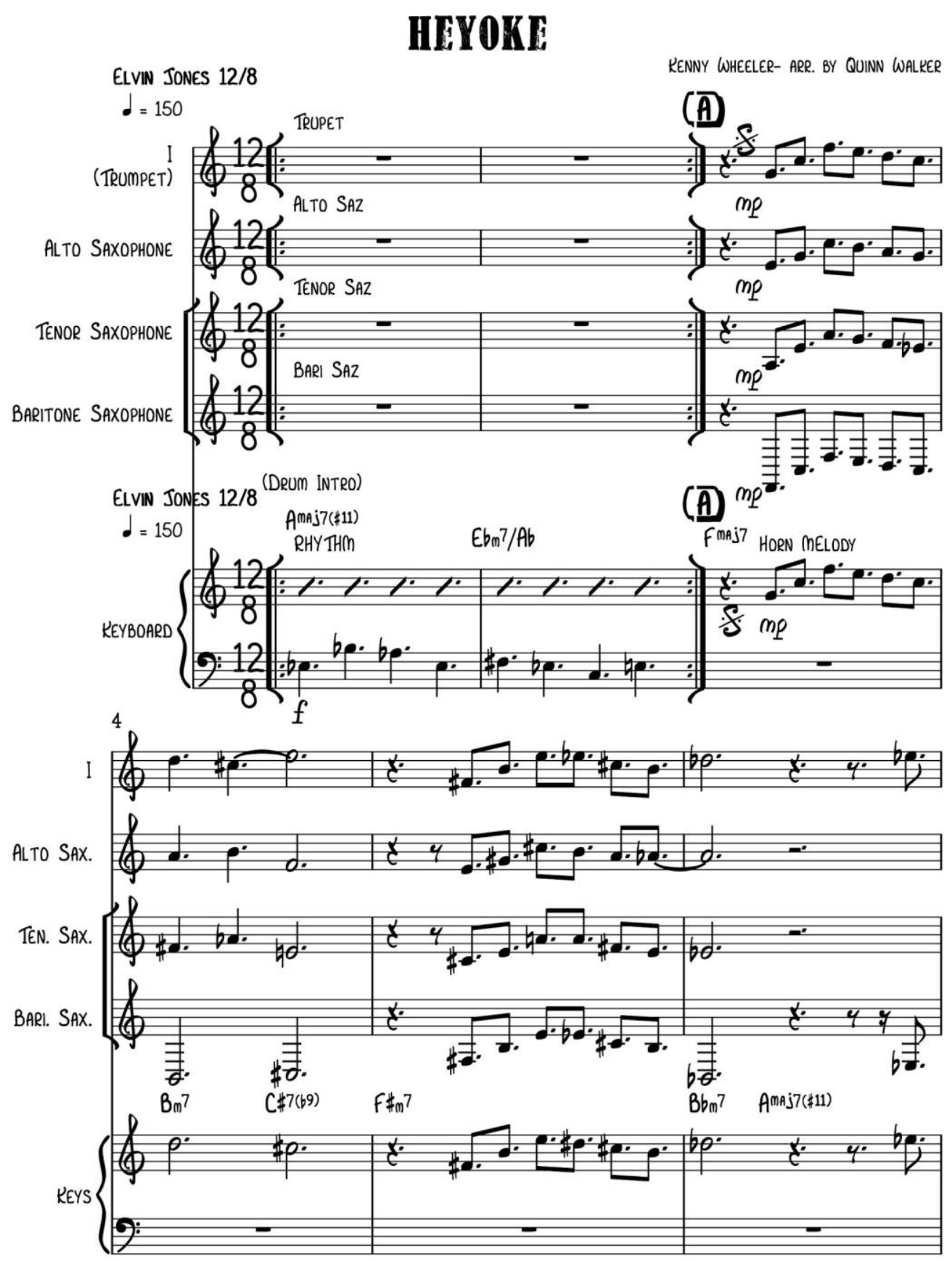

COPYRIGHT @ 2019 
Walker 27
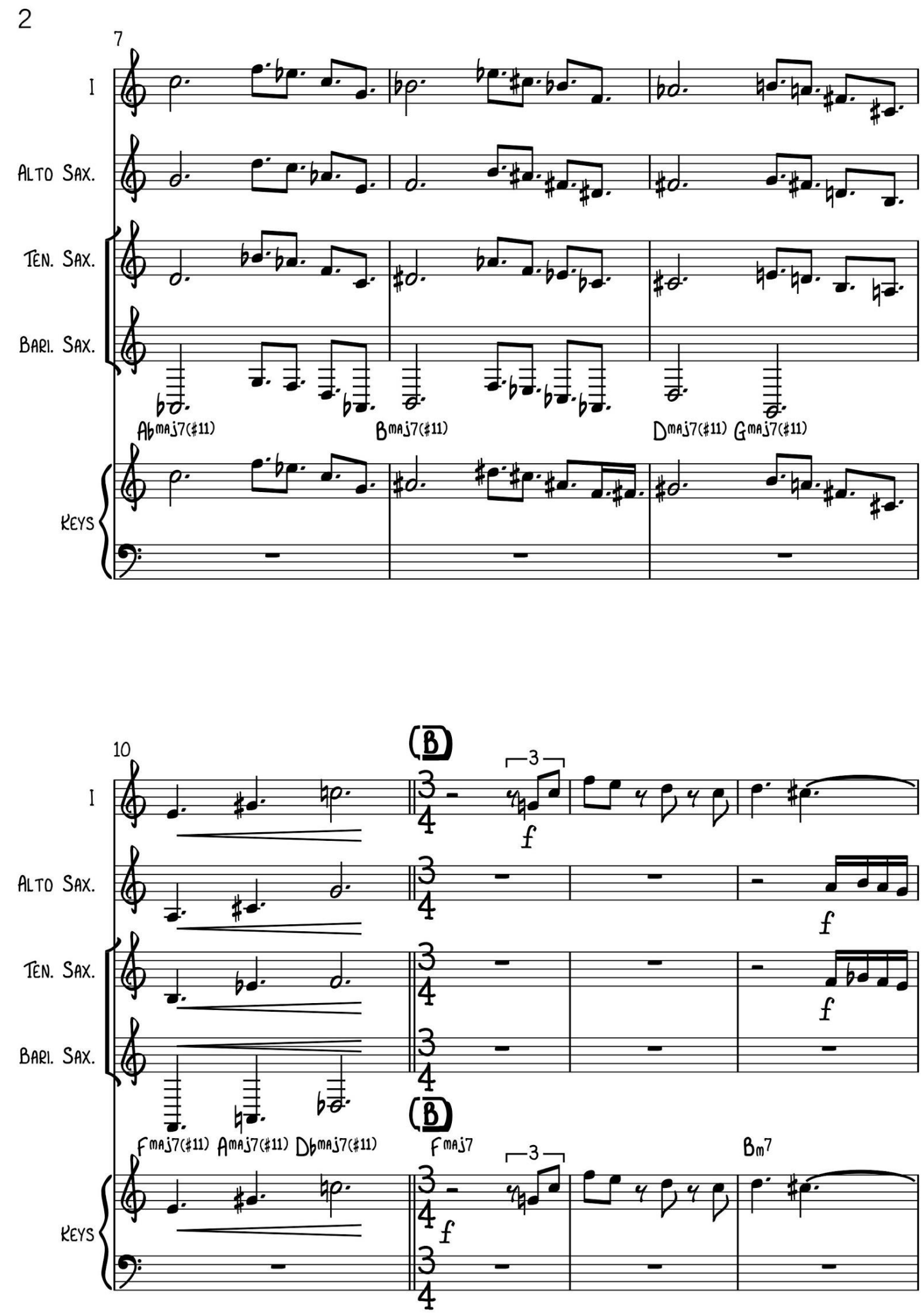

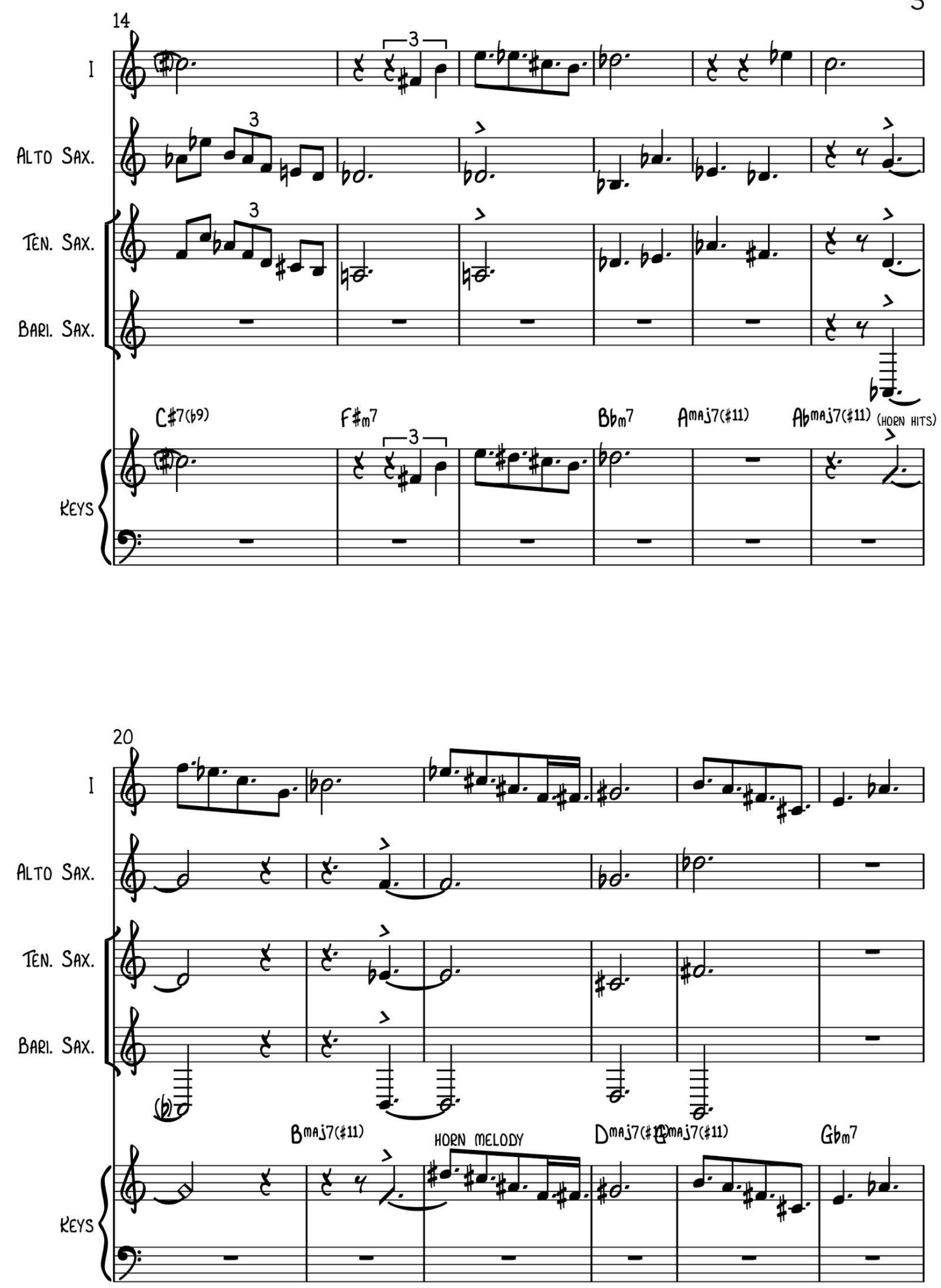
4
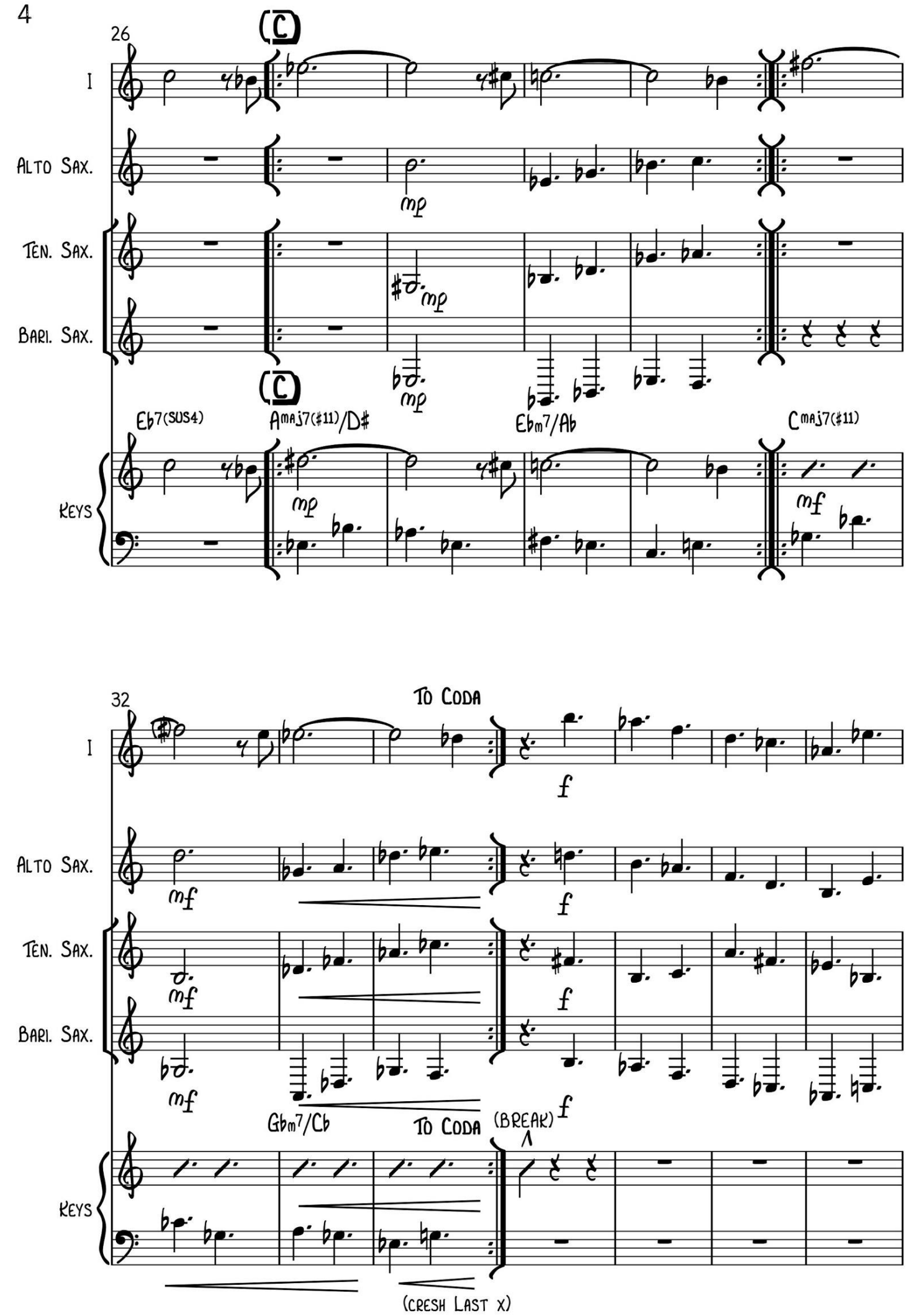
(D)

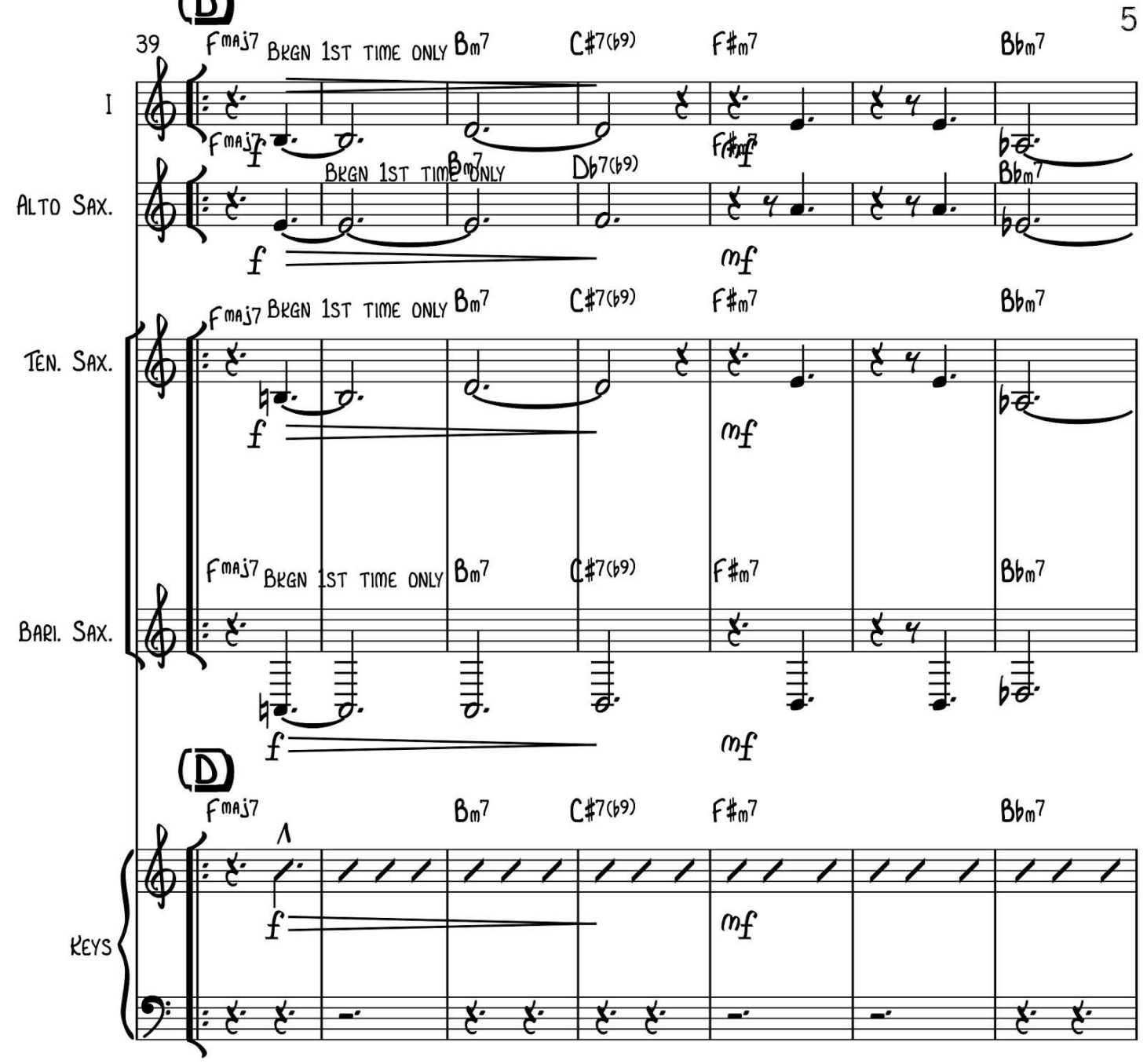


6

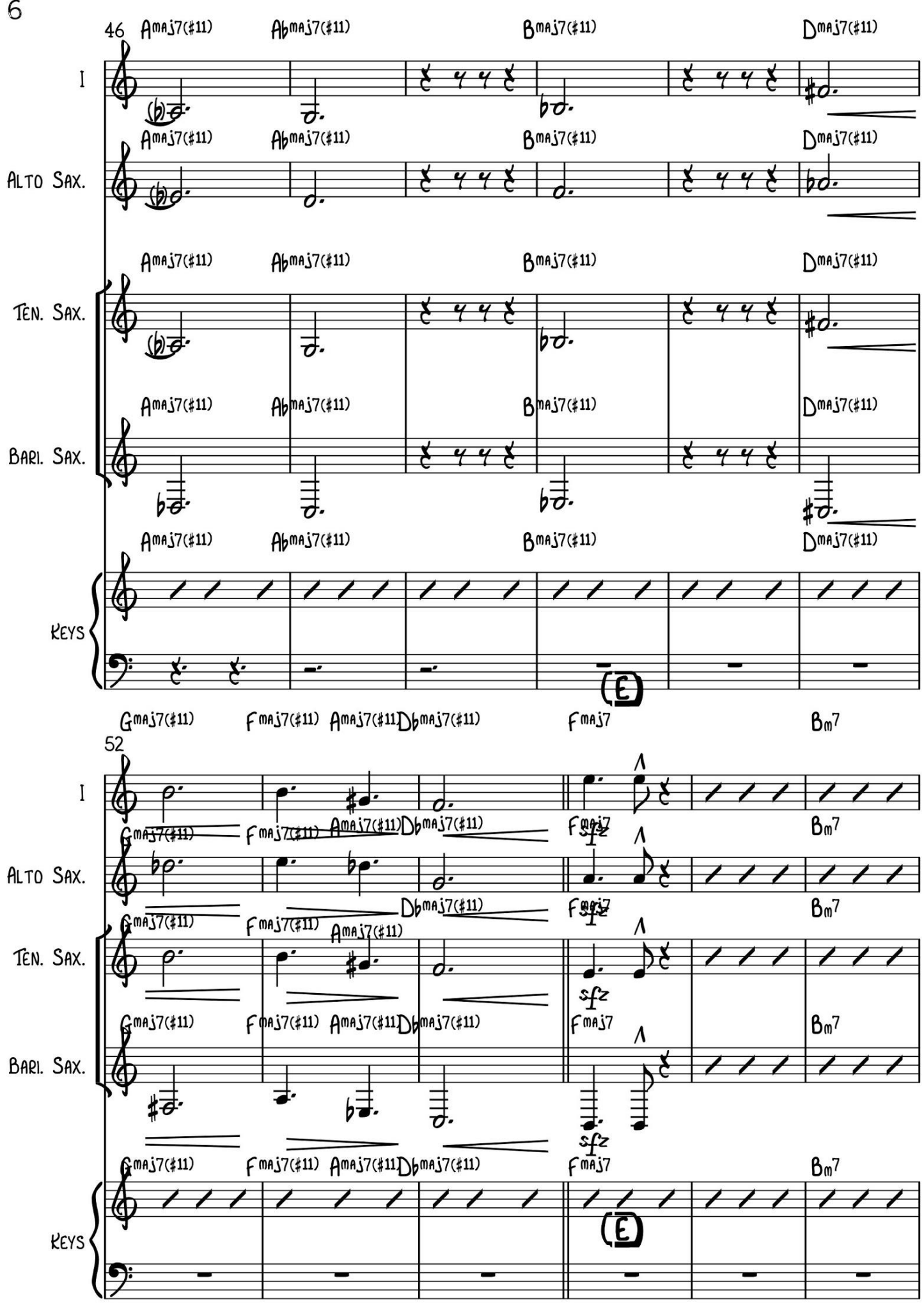


Walker 32
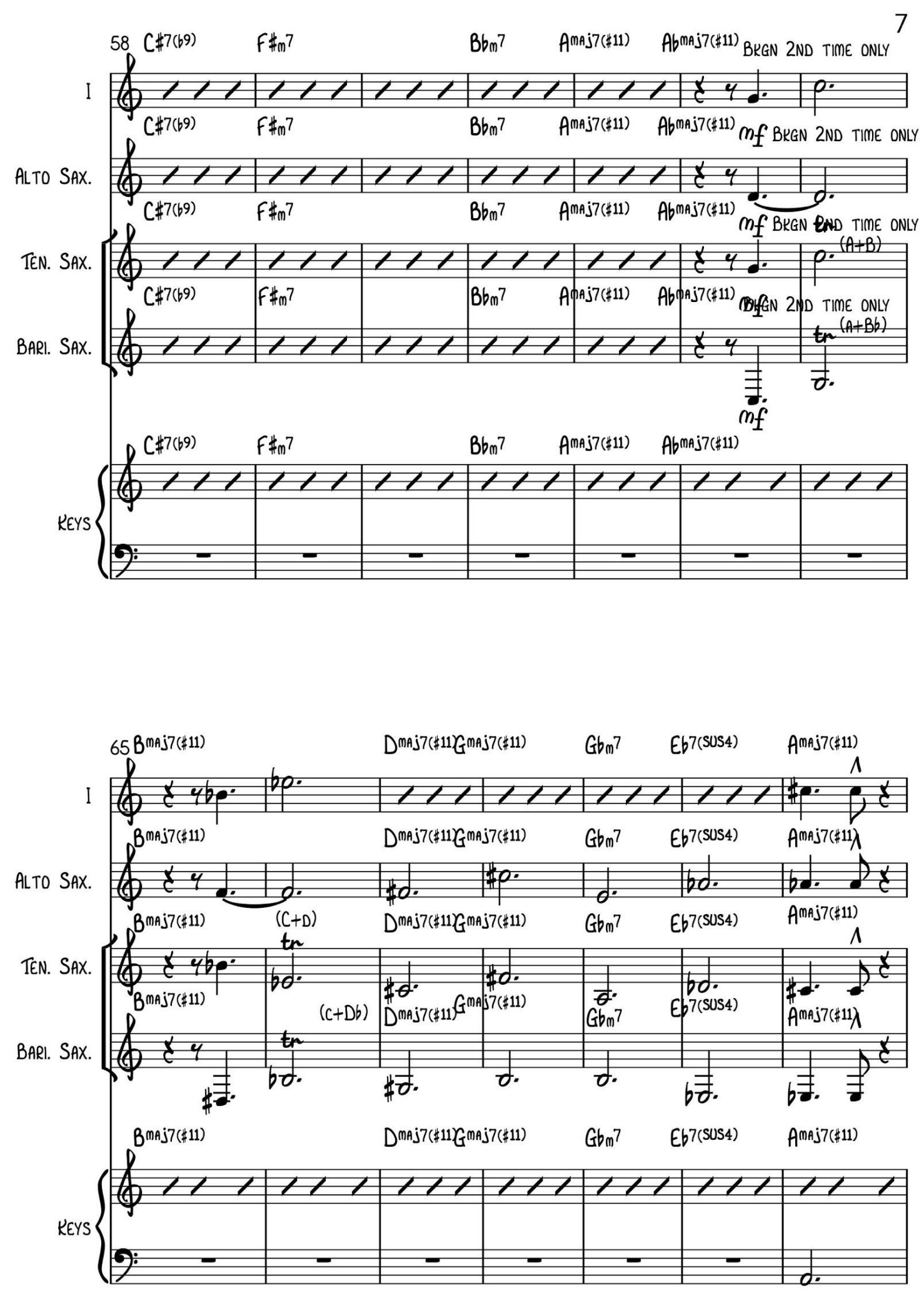
Walker 33

8
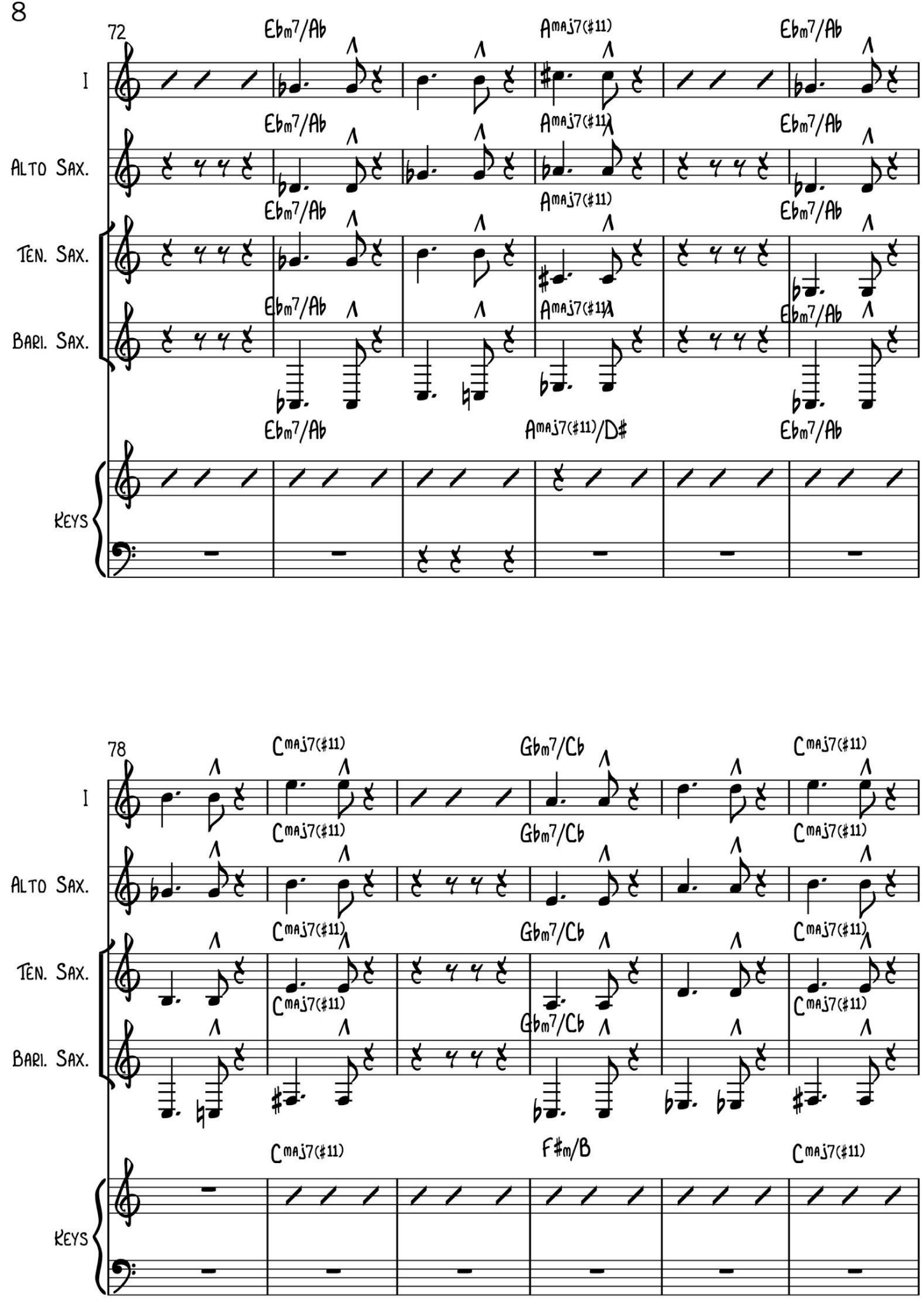

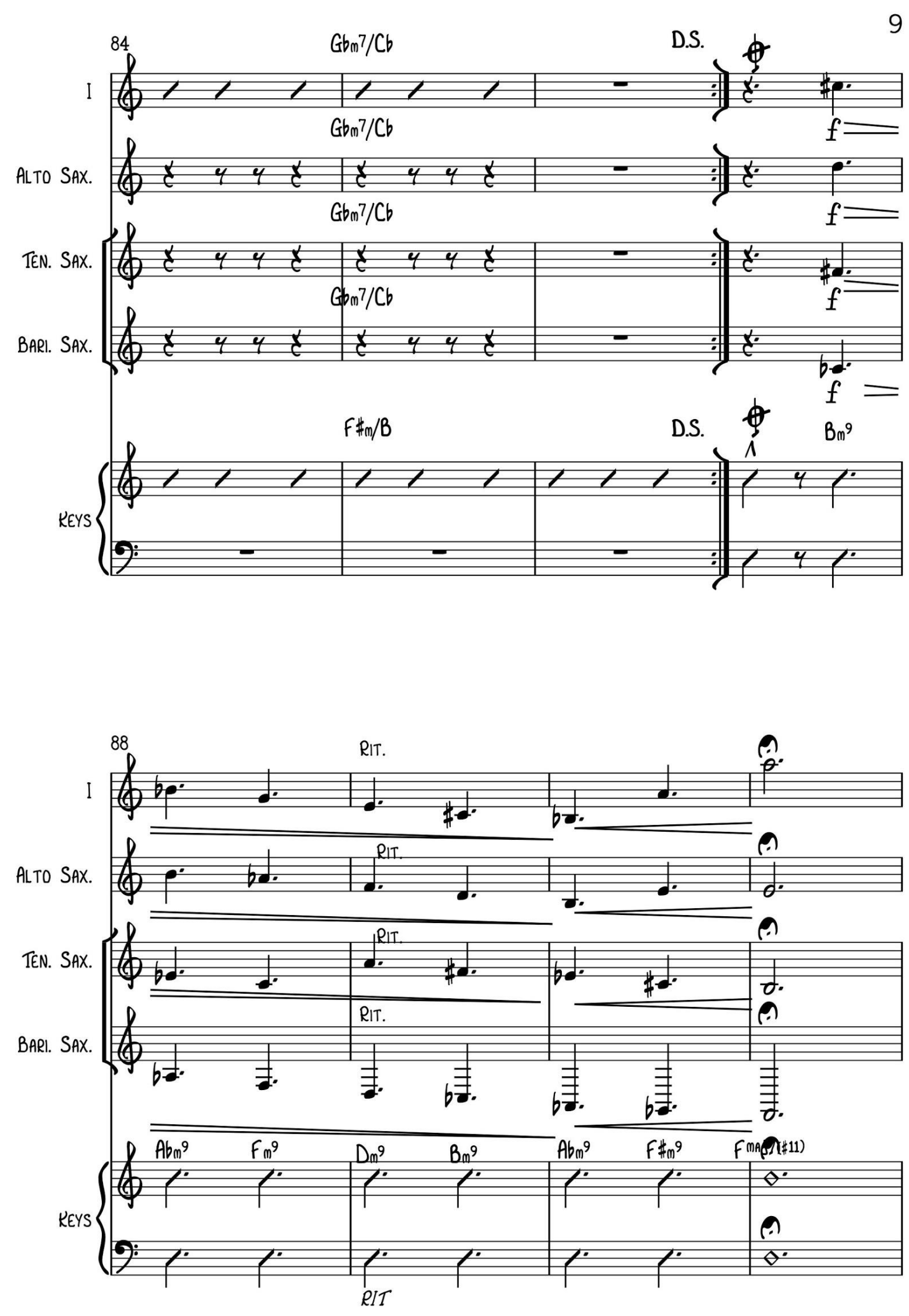
Walker 35

"March Mist"

\section{MARCH MIST}

ALLEGRETTO $d=150$

KENNY WHEELER
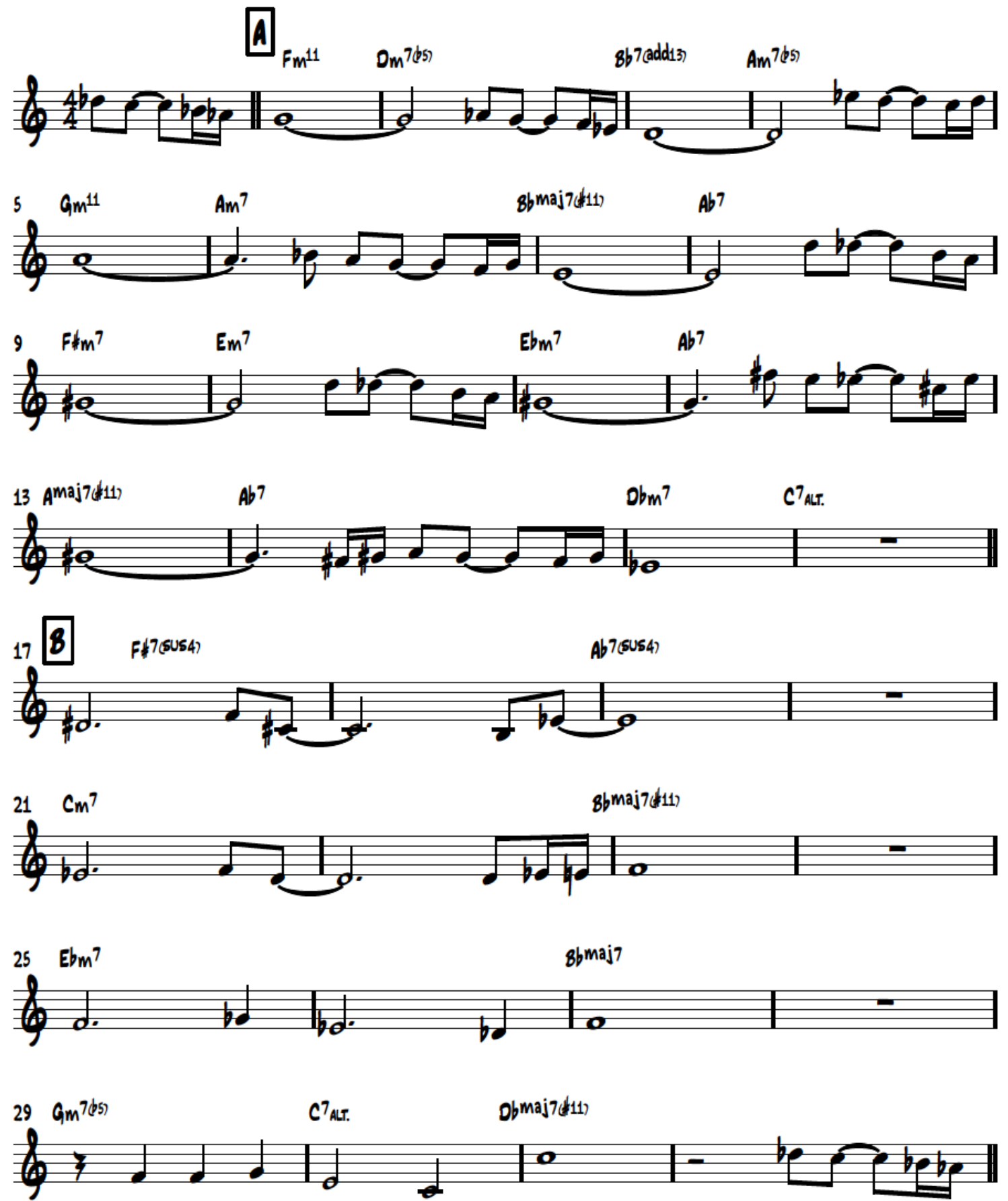